\title{
SISTEM PENDUKUNG KEPUTUSAN PENENTUAN PENERIMA BEASISWA DENGAN METODE SIMPLE ADDITIVE WEIGHTING DI SMPN 19 TANGERANG
}

\author{
Bayu Aji Kartiko', Agung Wibowo, M.Kom², Faridi, M.Kom ${ }^{3}$, Angga Aditya Permana, M.Kom ${ }^{4}$ \\ 1,2,3,4 Program Studi Teknik Informatika, Fakultas Teknik, Universitas Muhammadiyah Tangerang \\ J1. Perintis Kemerdekaan 1/33 Cikokol Kota Tangerang \\ Co Responden Email: agung@ft-umt.ac.id
}

Article history

Received Nov 17, 2020

Revised Jan 15, 2021

Accepted Jan 30, 2021

Available online Feb 05, 2021

Keywords

Decision Support System, Scholarship, Simple Additive Weighting (SAW) Method, Unified Model Language (UML).
Riwayat

Diterima 17 Nov 2020

Revisi 15 Jan 2021

Disetujui 30 Jan 2021

Terbit 05 Feb 2021

Kata Kunci

Sistem Pendukung Keputusan, Beasiswa, Metode Pembobotan Aditif Sederhana (SAW),

Bahasa Model Terpadu (UML).

\section{Abstract}

In determining scholarship recipients in schools manually, errors often occur causing inefficient management of scholarship data in terms of time and the absence of clear criteria for how students can obtain scholarships. To anticipate that mistakes do not occur, a Decision Support System is needed. One method that can be used is the Simple Additive Weighting (SAW) method. The data collection method used was the observation method to the school and the interview method with the related teachers regarding the scholarship acceptance. In this research, system development is carried out using the Waterfall method. And for system testing used Black-box Testing. The system design uses the Unified Model Language (UML), which includes usecase diagrams, activity diagrams, sequence diagrams and class diagrams. Then the program implementation uses the PHP programming language and MySQL database. This application will also display the value, criteria, alternatives and then a ranking of the scholarship recipient determination process. With this decision support system, the school will get the results of who is entitled to receive the scholarship.

Abstrak
Dalam menentukan penerima beasiswa di sekolah secara manual,
kesalahan sering terjadi menyebabkan manajemen data beasiswa yang
tidak efisien dalam hal waktu dan tidak adanya kriteria yang jelas tentang
bagaimana siswa dapat memperoleh beasiswa. Untuk mengantisipasiagar
kesalahan tidak terjadi, diperlukan Sistem Pendukung Keputusan. Salah
satu metode yang dapat digunakan adalah metode Simple Additive
Weighting (SAW). Metode pengumpulan data yang digunakan adalah
metode observasi ke sekolah dan metode wawancara dengan guru terkait
mengenai penerimaan beasiswa. Dalam penelitian ini, pengembangan
sistem dilakukan dengan menggunakan metode Waterfall. Dan untuk
pengujian sistem digunakan Black-box Testing. Desain sistem
menggunakan Bahasa Model Terpadu (UML), yang mencakup diagram
usecase, diagram aktivitas, diagram urutan, dan diagram kelas. Kemudian
implementasi program menggunakan bahasa pemrograman PHP dan
database MySQL. Aplikasi ini juga akan menampilkan nilai, kriteria,
alternatif dan kemudian peringkat proses penentuan penerima beasiswa.
Dengan sistem pendukung keputusan ini, sekolah akan mendapatkan
hasil siapa yang berhak menerima beasiswa tersebut.

Dalam menentukan penerima beasiswa di sekolah secara manual, kesalahan sering terjadi menyebabkan manajemen data beasiswa yang tidak efisien dalam hal waktu dan tidak adanya kriteria yang jelas tentang bagaimana siswa dapat memperoleh beasiswa. Untuk mengantisipasi agar kesalahan tidak terjadi, diperlukan Sistem Pendukung Keputusan. Salah satu metode yang dapat digunakan adalah metode Simple Additive Weighting (SAW). Metode pengumpulan data yang digunakan adalah metode observasi ke sekolah dan metode wawancara dengan guru terkait mengenai penerimaan beasiswa. Dalam penelitian ini, pengembangan sistem dilakukan dengan menggunakan metode Waterfall. Dan untuk pengujian sistem digunakan Black-box Testing. Desain sistem menggunakan Bahasa Model Terpadu (UML), yang mencakup diagram usecase, diagram aktivitas, diagram urutan, dan diagram kelas. Kemudian implementasi program menggunakan bahasa pemrograman PHP dan database MySQL. Aplikasi ini juga akan menampilkan nilai, kriteria, alternatif dan kemudian peringkat proses penentuan penerima beasiswa. hasil siapa yang berhak menerima beasiswa tersebut. 


\section{PENDAHULUAN}

Pendidikan merupakan langkah awal untuk membentuk kepribadian dalam mewujudkan kecerdasan bagi siswa. Di era global ini banyak masyarakat ingin melanjutkan ke jenjang sekolah menengah pertama sehingga memunculkan persaingan untuk menyajikan iklim akademik yang kondusif. Suasana kondusif dapat mendukung proses pembelajaran dan penciptaan prestasi. Untuk mewujudkan semua itu perlu adanya kerja sama antara Guru dengan Siswa agar mendapatkan hasil seleksi yang objektif, tidak memihak pada salah satu siswa.

Untuk menghindari subyektifitas keputusan yang dihasilkan, diperlukan suatu Sistem Pendukung Keputusan (SPK) yang dapat membantu pihak sekolah dalam memutuskan kriteria beasiswa untuk siswa berprestasi disekolah tersebut. Sistem Pendukung Keputusan (SPK) merupakan salah satu model yang dibangun untuk menyelesaikan masalah yang terstruktur. Untuk itulah, diperlukan suatu metode seleksi yang terstruktur, sintesis, transparan dan dapat dipertanggungjawabkan. Proses pengambilan keputusan pada dasarnya adalah memilih sesuatu yang alternatif. Metode yang cukup obyektif dapat membantu kerangka berfikir manusia dalam mengambil keputusan yang kompleks adalah Simple Additive Weighting (SAW).

Dimana metode ini dapat membantu dalam pengambilan keputusan suatu kasus, akan tetapi perhitungan dengan menggunakan metode SAW hanya menghasilkan nilai terbesar yang akan terpilih sebagai alernatif yang terbaik. Metode Simple Additive Weighting (SAW) membantu pengambilan keputusan memilih sebuah alternatif yang memberikan hasil paling mendekati tujuannya. Tujuan penelitian ini untuk membantu pihak sekolah menentukan siswa yang lebih berhak mendapatkan beasiswa. Penentuan beasiswa menjadi lebih teliti dan sesuai kriteria dalam penyeleksian penerima beasiswa. Sehingga membantu para penyeleksi mendapatkan waktu yang dibutuhkan dalam penentuan penerima beasiswa.

Oleh sebab itu penulis akan memberikan judul "Sistem Pendukung Keputusan Penentuan Penerima Beasiswa Dengan Metode Simple Additive Weighting Di Smpn 19 Tangerang".

\section{Konsep Dasar Sistem}

TINJAUAN PUSTAKA

Terhadap beberapa pendapat para ahli mengenai defisi sistem, diantaranya kelompok dasar sistem, diantaranya kelompok dasar pendekatan dalam mendefinisi sistem yaitu menekankan pada prosedur dan komponen atau elemenya.

Menurut Pratama (2014), "Sistem adalah sekumpulan prosedur yang saling berkaitan dan saling terhubung untuk melakukan suatu tugas bersama-sama. Secara garis besar, sebuah sistem informasi terdiri atas tiga komponen atas tiga komponen utama, ketiga komponen tersebut mencakup software, hardware, dan brainware. Ketiga kelompok ini saling berkaitan satu sama lain.

Menurut Hartono (2013), "Sistem adalah suatu himpunan dari berbagai bagian atau elemen, yang saling berhubungan secara terorganisasi berdasarkan fungs-fungsinya, menjadi satu kesatuan".

\section{Karakteristik Sistem}

Menurut Sutabri (2012), sebuah sistem mempunyai karakteristik atau sifat-sifat tertentu yang mencirikan bahwa hal tersebut bisa dikatakan sebagai suatu sistem.adapun karakteristik yang dimaksud adalah sebagi berikut :

\section{- Komponen (Component)}

Suatu sistem terdiri dari sejumlah komponen - komponen yang saling berinteraksi, yang artinya saling bekerja sama 
membentuk satu kesatuan. Komponen komponen sistem tersebut dapat berupa suatu subsistem. Setiap subsistem memiliki sifat dari sistem yang menjalankan suatu fungsi tertentu mempengaruhi proses sistem secara keseluruhan. Suatu sistem dapat mempunyai sistem yang lebih besar atau sering disebut "supra sistem".

\section{- Batasan sistem (Boundary)}

Batasan sistem merupakan daerah yang membatasi antara suatu sistem dengan sistem yang lain atau dengan lingkungan luarnya. Batasan sistem ini memungkinkan suatu sistem dipandang sebagai suatu kesatuan. Batasan suatu sistem menunjukkan ruang lingkup (scope) dari sistem tersebut.

- Lingkungan Luar Sistem (Environment)

Bentuk apapun yang ada diluar ruang lingkup atau batasan sistem yang mempengaruhi oprasi sistem tersebut disebut lingkungan luar. Lingkungan luar sistem ini dapat bersifat menguntungkan dan dapat juga bersifat merugikan sistem tersebut. Dengan demikian, lingkungan luar tersebut harus tetap dijaga dan dipelihara. Lingkungan luar yang merugikan harus dikendalikan. Kalau tidak, maka akan mengganggu kelangsungan hidup dari sistem tersebut.

\section{- Penghubung Sistem (Interface)}

Media yang menghubungkan sistem dengan subsistem yang lainya disebut penghubung sistem. Penghubung ini memungkinkan sumber-sumber daya mengalir dari satu subsistem kesubsistem yang lain. Bentuk keluaran dari satu subsistem akan menjadi masukan untuk subsistem lain melalui penghubung tersebut. Dengan demikian, dapat terjadi suatu integrasi sistem yang membentuk satu kesatuan.

\section{- Masukan Sistem (Input)}

Energi yang dimasukkan kedalam sistem yang dapat berupa perawatan (maintenace input), dan masukkan sinyal (signal input). Maintenace input adalah energi yang dimasukkan agar sistem dapat beroperasi. Signal input adalah enerig yang diproses untuk didapatkan keluaran. Contoh dalam sistem computer program adalah maintenance input sedangkan data adalah signal input untuk diolah menjadi informasi.

\section{- Keluaran sistem (Output)}

Keluaran sistem adalah hasil dari energi yang diolah dan diklasifikasikan menjadi keluaran yang berguna dan sisa pembuangan. Contoh komputer menghasilkan panas yang merupakan sisa pembuangan, sedangkan informasi adalah keluaran yang dibutuhkan.

- Pengolahan Sistem (Process)

Suatu sistem menjadi bagian pengolah yang akan mengubah masukkan menjadi keluaran. Sistem produksi akan mengolah bahan baku menjadi bahan jadi, sistem akuntansi akan mengolah data menjadi laporanlaporan keuangan.

- Sasaran Sistem (Objevtive)

Suatu sistem memiliki tujuan dan sasaran yang pastidan bersifat deterministic. Jika suatu sistem tidak memiliki sasaran maka operasi sistem tidak ada gunanya. Suatu sistem dikatakan berhasil bila mengenai sasaran atau tujuan yang telah direncanakan.

\section{Sistem Pendukung Keputusan}

Sistem Pendukung Keputusan (SPK)

atau Decision Support System (DSS) merupakan sebuah sistem yang mampu memberikan kemampuan pemecahan masalah maupun kemampuan pengkomunikasian untuk masalah dengan kondisi semi terstruktur dan tak terstruktur. Sistem ini digunakan untuk membantu pengambilan keputusan dalam situasi semi terstruktur dan situasi yang tidak terstruktur, dimana tak seorangpun tahu secara pasti bagaimana keputusan seharusnya dibuat.

Muslihudin dan Oktafianto (2016) mengatakan bahwa, "Decisin Support System merupakan sistem informasi pada level manajemen dari suatu organisasi yang mengombinasikan data dan model analisis canggih atau peralatan data analisis untuk mendukung pengambilan yang semi terstruktur dan tidak terstruktur, DSS direncanakan untuk membantu pengambilan keputusan organisasional". 


\section{Karakteristik dan Kapabilitas Sistem Pendukung Keputusan}

Karakteristik dan Kapabilitas SPK menurut Turban, Sharda \& Delen (2011), adalah sebagai berikut :

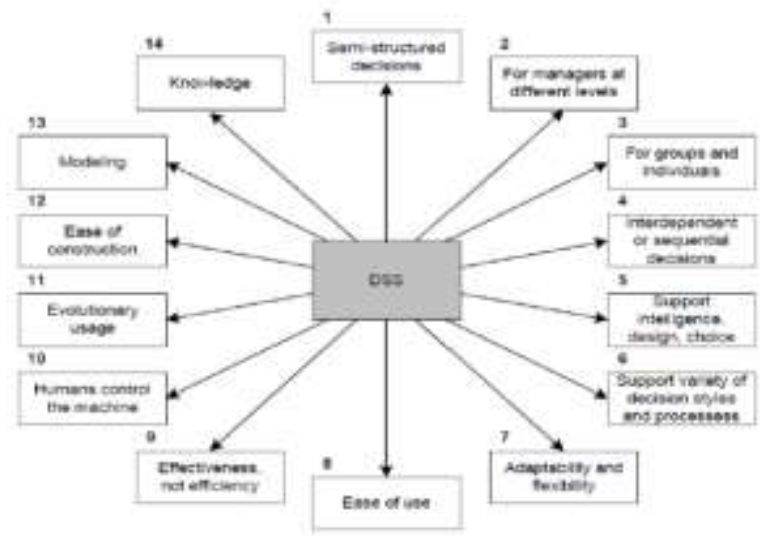

Gambar 2.2 Karakteristik dan Kapabilitas SPK

1. SPK menyediakan dukungan bagi pengambil keputusan terutama padasituasi terstruktur dan tak terstruktur dengan memadukan pertimbangan manusia dan informasi terkomputerisasi.

2. Dukungan untuk semua level manajerial, mulai dari eksekutif puncak sampai manajer lapangan.

3. Dukungan untuk individu dan kelompok. Masalah yang kurang terstruktur sering memerlukan keterlibatan individu dari departemen dan tingkat organisasional yang berbeda atau bahkan dari organisasi lain.

4. Dukungan untuk keputusan independen dan atau sekuensial. Keputusan dapat dibuat satu kali, beberapa kali atau berulang (dalam interval yang sama).

5. Dukungan pada semua fase proses pengambilan keputusan : intelegensi, desain, pilihan dan implementasi.

6. Dukungan diberbagai proses dan gaya pengambilan keputusan.

\section{Komponen Sistem Pendukung Keputusan}

Menurut Turban, Sharda \& Delen (2011), Decision Support System (Sistem Pendukung Keputusan) terdiri dari empat subsistem yang saling berhubungan yaitu:

1. Subsistem Manajemen Data

Subsistem manajemen data meliputi basis data yang terdiri dari data-data yang relevan dengan keadaan dan dikelola oleh software yang disebut Database Management System (DBMS). Manajemen data dapat diinterkoneksikan dengan data warehouse perusahaan, suatu repositori untuk data perusahaan yang relevan untuk mengambil keputusan.

\section{Subsistem Manajemen Model}

Subsistem manajemen model berupa paket software yang berisi model-model finansial, statistik, ilmu manajemen, atau model kuantitatif yang menyediakan kemampuan analisa dan manajemen software yang sesuai. Software ini disebut sistem manajemen basis model.

3. Subsistem Dialog (User Interface Subsystem)

Subsistem dialog (User Interface Subsystem) merupakan subsistem yang dapat digunakan oleh user untuk berkomunikasi dengan sistem dan juga member perintah SPK. Web browser memberikan struktur antarmuka pengguna grafis yang familiar dan konsisten. Istilah antarmuka pengguna mencakup semua aspek komunikasi antara pengguna dengan sistem.

4. Subsistem Manajemen Berbasis Pengetahuan (Knowledge-Based Management Subsystem)

Subsistem manajemen berbasis pengetahuan merupakan subsistem yang dapat mendukung subsistem lain atau berlaku sebagai komponen yang berdiri sendiri (independent).

\section{Manfaat Sistem Pendukung Keputusan}

Sistem pendukung keputusan juga memiliki keuntungan atau manfaat. Adapun keuntungan dari Sistem Pendukung Keputusan adalah sebagai berikut : 
1. Sistem pendukung keputusan memperluas kemampuan pengambil keputusan dalam memproses data.

2. Kecepatan simulasi memberikan kemampuan bagi kita untuk mengevaluasi dampak keputusan dengan waktu yang singkat.

\section{Simple Additive Weighting (SAW)}

Menurut Nofriyansyah (2014), "Metode simple additive weighting sering juga dikenal dengan istilah metode penjumlahan terbobot. Konsep dasar simple additive weighting adalah mencari penjumlahan terbobot dari kinerja setiap alternatif pada semua atribut. Metode simple additive weighting membutuhkan proses normalisasi matriks keputusan (X) ke suatu skala yang dapat diperbandingkan dengan semua rating alternatif yang ada".

Formula untuk melakukan normalisasi tersebut adalah sebagai berikut:

$$
\operatorname{Rij} \begin{cases}\frac{x_{i j}}{\max x_{i j}} & \text { Jika j adalah atribut } \\
\frac{\min x_{i j}}{x_{i j}} & \begin{array}{l}
\text { keuntungan (benefit) } \\
\text { biaya (cost) }
\end{array}\end{cases}
$$

Dimana rij adalah $\mathrm{r}$. dari alternatif $\mathrm{Ai}$ pada atribut $\mathrm{Cj}: \mathrm{i}=$ $1,2, \ldots, \mathrm{m}$ dan $\mathrm{j}=1,2, \ldots, \mathrm{n}$.

Keterangan :

Rij : Rating kinerja ternormalisasi

Max Xij : Nilai maksimum dari setiap baris dan

Min Xij : Nilai minimum dari setiap baris dan kolom

Xij $\quad$ : Baris dan kolom dari matriks

Benefit : Jika nilai terbesar adalah terbaik

Cost

: Jika nilai terkecil adalah terbaik

$$
V_{i}=\sum_{j=1}^{n} w_{j} r_{i j}
$$

Nilai Preferensi untuk setiap alternatif (Vi) diberikan rumus sebagai berikut :
Dimana :

Vi : Ranking untuk setiap alternatif

$\mathrm{Wj}$ : Nilai bobot rangking (dari setiap kriteria)

rij : Nilai rating kinerja ternormalisasi

Nilai Vi yang lebih besar, mengindikasikan bahwa alternatif Ai lebih terpilih.

Langkah-langkah penyelesaiannya sebagai berikut :

- Menentukan kriteria-kriteria yang akan dijadikan acuan dalam mengambilan keputusan, yaitu $\mathrm{Ci}$.

- Menentukan rating kecocokan setiap alternatif pada setiap kriteria.

- Membuat matriks keputusan berdasarkan kriteria (Ci), kemudian melakukan normalisasi matriks berdasarkan persamaan yang disesuaikan dengan jenis atribut (atribut keuntungan ataupun atribut biaya) sehingga diperoleh matriks ternormalisasi $\mathrm{R}$.

- Hasil akhir diperoleh dari proses perankingan yaitu penjumlahan.

- Dari perkalian matriks ternormalisasi $\mathrm{R}$ dengan vector bobot sehingga diperoleh nilai terbesar yang dipilih sebagai alternatif terbaik (Ai) sebagai solusi.

\section{Beasiswa}

Pengertian beasiwa menurut ahli yaitu sebagai berikut :

Menurut Murniasih (2010) beasiswa diartikan sebagai bentuk penghargaan yang diberikan kepada individu agar dapat melanjutkan pendidikan ke jenjang yang lebih tinggi. Penghargaan itu dapat berupa akses tertentu pada suatu institusi atau penghargaan berupa bantuan keuangan. Pada dasarnya, beasiswa adalah penghasilan bagi yang menerimanya. 


\section{Tujuan Beasiswa}

Beasiswa - beasiswa yang diberikan kepada pelajar atau mahasiswa bertujusn untuk beberapa hal diantaranya :

- Menghasilkan sumber daya manusia yang berpotensi untuk berperan dalam mempercepat pembangunan bangsa menuju pada kemandirian di tengahtengah percaturan global.

- Mewujudkan keadilan dan demokratisasi dalam bidang pendidikan dengan memberikan beasiswa kepada mahasiswa yang berprestasi.

- Memberikan bantuan dana kepada mahasiswa yang mengalami kendala secara ekonomis dan atau geografis.

Pemberian beasiswa yang tepat sasaran akan memberikan pemerataan kepada pelajar dan mahasiswa untuk dapat mencapai prestasi akademik yang tinggi meskipun secara ekonomi sedikit mengalami hambatan. Pemberian beasiswa berupaya mendorong pelajar dan mahasiswa untuk tetap menjaga kelangsungan studi dan berprestasi. Beasiswa yang diberikan kepada mahasiswa tentu mengandung konsekuensi yang perlu dijalani pelajar dan mahasiswa.

\section{Jenis - jenis Beasiswa}

Menurut Murniasih (2010), ada beberapa jenis beasiswa yaitu:

\section{Beasiswa Penghargaan}

Beasiswa ini biasanya diberikan kepada kandidat yang memiliki keunggulan akademik. Beasiswa ini diberikan berdasarkan prestasi akademik mereka secara keseluruhan. Misalnya, dalam bentuk Indeks Prestasi Kumulatif (IPK). Meski sangat kompetitif, beasiswa ini ada dalam berbagai bentuk.

2. Beasiswa Bantuan

Jenis beasiswa ini adalah untuk mendanai kegiatan akademik para mahasiswa yang kurang beruntung, tetapi memiliki prestasi. Komite beasiswa biasanya memberikan beberapa penilaian pada kesulitan ini, misalnya, seperti pendapatan orangtua, jumlah saudara kandung yang sama-sama tengah menempuh studi, pengeluaran, biaya hidup, dan lain-lain.

\section{Beasiswa Atletik}

Universitas biasanya merekrut atlet populer untuk diberikan beasiswa dan dijadikan tim atletik perguruan tinggi mereka. Banyak atlet menyelesaikan pendidikan mereka secara gratis, tetapi membayarnya dengan prestasi olahraga. Beasiswa seperti ini biasanya tidak perlu dikejar, karena akan diberikan keada mereka yang memiliki prestasi.

\section{Beasiswa Penuh}

Banyak orang menilai bahwa beasiswa diberikan kepada penerimanya untuk menutupi keperluan akademik secara keseluruhan. Jika Anda benar-benar beruntung, tentunya Anda akan mendapatkan beasiwa seperti ini. Beasiswa akan diberikan untuk menutupi kebutuhan hidup, buku, dan biaya pendidikan. Namun, banyak beasiswa lainnya meng-cover biaya hidup, buku, atau sebagian dari uang sekolah.

Berdasarkan penjelasan di atas, dapat disimpulkan bahwa berbagai bentuk beasiswa yang terdapat di Indonesia, akan tetapi ini hanya sebagian kecil bentuk beasiswa yang ada.

\section{METODE PENELITIAN} Metode Pengumpulan Data

Untuk mendapatkan data yang diperlukan dalam penulisan laporan tugas akhir ini penulis menggunakan dua jenis data pada penelitian, yaitu data primer dan data skunder.

\section{Data Primer}

Data ini diperoleh secara langsung melalui wawancara antara peneliti dengan guru bagian kesiswaan. Hasil wawancara ini selanjutnya akan dijadikan sumber data untuk membuat sistem pendukung keputusan penentuan penerima beasiswa.

2. Data Sekunder 
Data ini diperoleh melalui data yang berupa berkas syarat untuk mengajukan beasiswa. Selain data yang di peroleh dari bagian kesiswaan, peneliti juga telah mendapatkan data melalui studi pustaka.

\section{Metode Penelitian}

Dalam melakukan proses penelitian ada 2 metode yang digunakan, yaitu :

\section{Observasi Langsung}

Dalam hal ini penulis melakukan pengamatan ke tempat observasi yaitu di SMPN 19 untuk mendapatkan data secara umum dengan melihat langsung, mengamati dan mencatat setiap proses yang sedang berjalan saat ini serta melihat format-format yang dilakukan saat ini.

2. Wawancara

Dalam hal ini penulis melakukan wawancara langsung dengan guru atau staf sekolah yang berkaitan untuk melengkapi bahan yang sudah ada selama observasi. Lalu penulis melakukan tanya jawab kepada bapak Agus selaku guru dan staf bagian kesiswaan yang berkaitan dengan sistem yang sedang diteliti.

\section{Pengembangan Perangkat Lunak}

Metode pengembangan yang digunakan dalam penelitian ini adalah metode waterfall. Berikut ini adalah penjelasan dari metode waterfall :

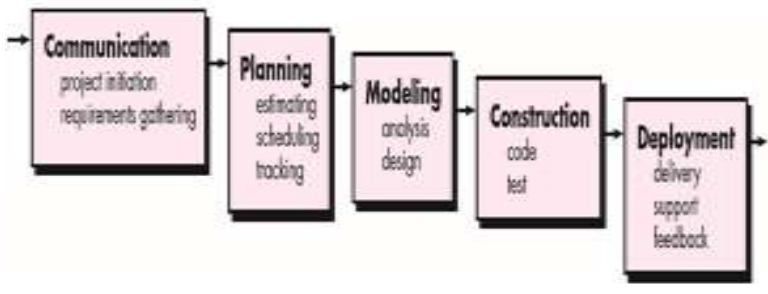

Gambar 3.1 Metode Waterfall (Pressman 2010)

Berikut ini adalah penjelasan dari Metode waterfall :

\section{Comunication (komunikasi)}

Pada tahap pertama ini, terdiri dari project initation dan requirements gathering.

\section{a. Project initiation (Inisiasi Projek)}

Pada tahap inisiasi projek ini, yang dilakukan peneliti adalah pengumpulan data-data yang sudah didapat dari hasil wawancara dengan guru atau staf yang berkaitan tentang beasiswa di SMPN 19.

\section{b. Requirements gathering}

Pada tahap ini peneliti melakukan pengumpulan data kebutuhan user yang belum terpenuhi, dan menentukan kebutuhan apa saja yang bisa memenuhi kebutuhan user.

2. Planning (Perencanaan)

Pada tahap selanjutnya, terdiri dari estimating, scheduling, dan tracking.

\section{- Estimating}

Pada tahap ini, peneliti membutuhkan biaya dan waktu dalam perancangan sistem pakar ini. Peneliti membutuhkan waktu selama 3 bulan untuk bisa menyelesaikan aplikasi sistem pendukung keputusan ini.

\section{- Scheduling}

Pada tahap penjadwalan, peneliti melakukan pembuatan rincian waktu yang dibutuhkan dalam proses pembuatan sistem yang peneliti buat.

3. Modeling

Pada tahap modeling, terdiri dari analysis dan design.

- Analysis

Pada tahap analisis, peneliti melakukan pengumpulan data kebutuhan secara intensif untuk menspesifikasikan kebutuhan perangkat lunak agar dapat dipahami seperti apa yang dibutuhkan oleh pengguna.

- Design

Pada tahap desain,. setelah menganalisis kebutuhan, selanjutnya peneliti membuat desain rancangan yang terdiri dari desain database, desain UML, dan desain rancangan antarmuka.

\section{Construction}

Pada tahap ini, terdiri code (pengkodean) dan test. 


\section{- $\quad$ Code (pengkodean)}

Pada tahap pengkodean ini, peneliti mulai melakukan pembuatan kode program sesuai dengan desain yang telah dibuat oleh peneliti pada tahap desain.

- Test

Pada tahap ini, peneliti fokus pada sistem yang sudah dibuat dari segi logic dan fungsional, juga memastikan bahwa semua bagian harus sudah diuji. Hal ini dilakukan untuk meminimalisir kesalahan (error) dan memastikan output yang dihasilkan sesuai dengan yang diinginkan dengan melakukan tes menggunakan black box testing.

\section{Deployment}

Pada tahapan akhir ini, terdiri dari delivery, support, dan feedback.

\section{- Delivery}

Pada tahap ini, peneliti akan melakukan penginstalan atau mempublish sistem pendukung keputusan yang telah dibuat dan kemudian akan digunakan oleh admin dalam proses penentuan beasiswa.

\section{- Support}

Pada tahap ini, peneliti memberikan bantuan berupa informasi tentang bagaimana penggunaan sistem pendukung keputusan yang telah peneliti buat agar dapat digunakan sesuai aturan yang telah ditentukan.

- Feedback

Pada tahap feedback, peneliti meminta pihak sekolah untuk memberikan masukan berupa saran, apakah sistem yang sudah dibuat oleh peneliti layak digunakan.

\section{HASIL DAN PEMBAHASAN}

\section{Analisis Sistem Berjalan}

Analisis sistem yang sedang berjalan merupakan salah satu cara atau teknik menguraikan masalah dan mencari gambaran dari sistem yang ada atau sistem yang sedang berjalan, apakah tetap dipertahankan atau tidak.
Langkah ini diperlukan untuk mengetahui kelemahan dari sistem yang berjalan. Berikut gambaran flowmap dari sistem yang ada :

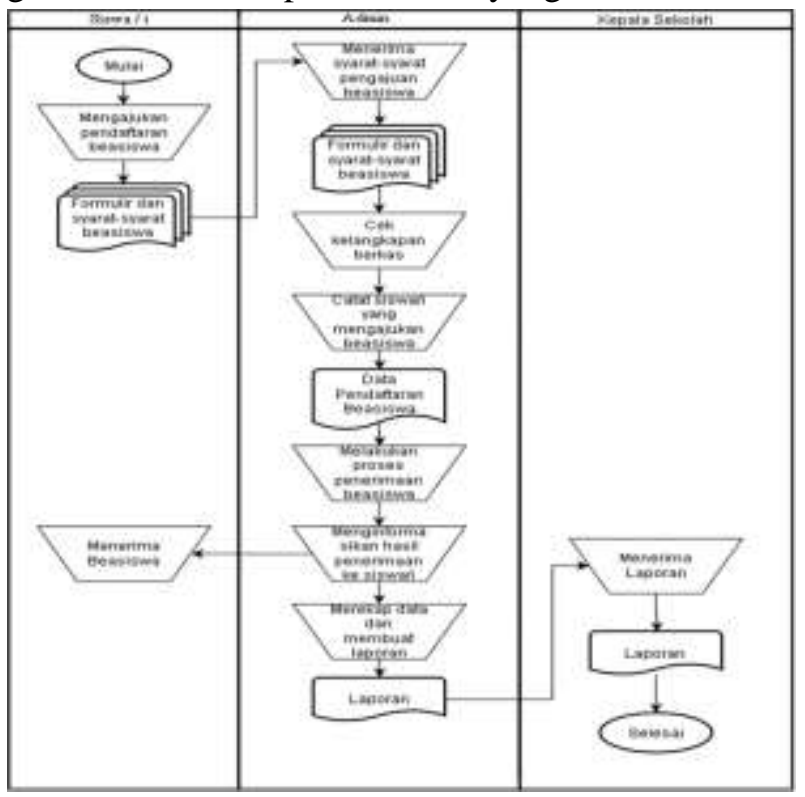

Gambar 4.1 Flowmap Proses Penentuan Beasiswa

\section{Perhitungan Manual Penentuan Beasiswa dengan Metode SAW}

Pada penelitian ini, dalam menentukan beasiswa menggunakan metode Simple Additive Weighting (SAW) diperlukan kriteria - kriteria dan bobot untuk melakukan perhitungan sehingga akan didapat alternatif terbaik.

Dalam penelitian ini penyeleksian yang akan menjadi alternatif ada 3, yaitu:

$$
\begin{aligned}
& \text { A1 }=\text { Aliza } \\
& \text { A2 }=\text { Shelly } \\
& \text { A3 }=\text { Tiara }
\end{aligned}
$$

Kriteria yang digunakan sebagai acuan ada 4, yaitu :

$$
\begin{aligned}
& \mathrm{C} 1=\text { Absensi } \\
& \text { C2 }=\text { Rapot } \\
& \text { C3 }=\text { Kepribadian } \\
& \text { C4 }=\text { Ekstrakurikuler } \\
& \text { Tingkat kepentingan } \\
& \text { angka } 1 \text { sampai denga } \\
& 1=\text { Sangat Buruk } \\
& \text { 2 = Buruk } \\
& 3=\text { Cukup } \\
& 4=\text { Baik } \\
& 5=\text { Sangat Baik }
\end{aligned}
$$$$
\text { Tingkat kepentingan setiap kriteria }
$$
dengan angka 1 sampai dengan 5, yaitu: 
Bobot preferensi dari setiap kriteria, yaitu : W $=(4,3,2,4)$

Nilai - nilai kriteria untuk setiap alternatif :

Tabel 4.1 Nilai Kriteria Untuk Setiap Alternatif

\begin{tabular}{|l|l|l|l|l|}
\hline \multirow{2}{*}{ Alternatif } & \multicolumn{2}{|l|}{ Kriteria } & \multicolumn{2}{l|}{} \\
\cline { 2 - 5 } & Absensi & Rapot & Kepribadian & $\begin{array}{l}\text { Ekstra- } \\
\text { kurikuler }\end{array}$ \\
\hline Aliza & 3 & 4 & 4 & 3 \\
\hline Shelly & 2 & 5 & 2 & 4 \\
\hline Tiara & 4 & 2 & 3 & 4 \\
\hline
\end{tabular}

Sebelumnya akan dilakukan perbaikan bobot terlebih dahulu. Nilai bobot awal $\mathrm{W}=$ Nilai kriteria yang telah ditentukan. Bobot nilai yang ditentukan yaitu:

$$
\begin{aligned}
& \mathrm{W}=(4,3,2,4) \text { di mana }: \\
& 1=\text { Sangat Buruk } \\
& 2=\text { Buruk } \\
& 3=\text { Cukup } \\
& 4=\text { Baik } \\
& 5=\text { Sangat Baik }
\end{aligned}
$$

Bobot nilai $\mathrm{W}=(4,3,2,4)$ diperbaiki dan menghasilkan :

$$
\begin{aligned}
& W 1=\frac{4}{4+3+2+4}=\frac{4}{13}=0.31 \\
& W 2=\frac{3}{4+3+2+4}=\frac{3}{13}=0.23 \\
& W 3=\frac{2}{4+3+2+4}=\frac{2}{13}=0.15 \\
& W 4=\frac{4}{4+3+2+4}=\frac{4}{13}=0.31
\end{aligned}
$$

Setelah menentukan nilai kriteria maka selanjutnya membuat matrix keputusan $\mathrm{X}$ yang dibentuk dari table rating kecocokan dari setiap alternatif pada setiap kriteria seperti pada persamaan di bawah ini:

$$
X=\left(\begin{array}{llll}
3 & 4 & 4 & 3 \\
2 & 5 & 2 & 4 \\
4 & 2 & 3 & 4
\end{array}\right)
$$

Melakukan matix keputusan X dengan cara menghitung nilai rating kinerja ternormalisasi (rij) dari alternatif $\mathrm{Ai}$ pada kriteria Ci seperti pada persamaan di bawah ini:

$R i j=\left(\begin{array}{l}\frac{X i j}{\max X i j} \\ \frac{\min X i j}{X i j}\end{array}\right) \begin{aligned} & \text { Jika } \mathrm{j} \text { adalah atribut } \\ & \text { keuntungan (benefit) } \\ & \text { Jika j adalah atribut biaya } \\ & (\text { cost })\end{aligned}$

Keterangan :

$\mathrm{Rij}=$ Nilai rating kinerja ternormalisasi

$\mathrm{Xij}=$ Nilai atribut yang dimiliki dari setiap kriteria

Max Xij = Nilai terbesar dari setiap kriteria Min Xij = Nilai terkecil dari setiap kriteria Benefit $=$ Jika nilai terbesar adalah terbaik Cost $=$ Jika nilai terkecil adalah terbaik

Karena setiap nilai yang diberikan pada setiap alternative di setiap kriteria merupakan nilai kecocokan (nilai terbesar adalah terbaik) maka semua kriteria yang diberikan diasumsikan sebagai kriteria keuntungan. Pertama-tama, dilakukan normalisasi matrix X seperti pada persamaan di bawah ini :

Normalisasi C1

$$
\begin{gathered}
R 11=\frac{\min (3 ; 2 ; 4)}{3}=\frac{2}{3}=0,67 \\
R 21=\frac{\min (3 ; 2 ; 4)}{2}=\frac{2}{2}=1 \\
R 31=\frac{\min (3 ; 2 ; 4)}{4}=\frac{2}{4}=0,5
\end{gathered}
$$

Normalisasi $\mathrm{C} 2$

$$
\begin{aligned}
R 12 & =\frac{4}{\max \{4 ; 5 ; 2\}}=\frac{4}{5}=0,8 \\
R 22 & =\frac{5}{\max \{4 ; 5 ; 2\}}=\frac{5}{5}=1 \\
R 32 & =\frac{2}{\max \{4 ; 5 ; 2\}}=\frac{2}{5}=0,4
\end{aligned}
$$

Normalisasi C3

$$
\begin{gathered}
R 13=\frac{4}{\max \{4 ; 2 ; 3\}}=\frac{4}{4}=1 \\
R 23=\frac{2}{\max \{4 ; 2 ; 3\}}=\frac{2}{4}=0.5 \\
R 33=\frac{3}{\max \{4 ; 2 ; 3\}}=\frac{3}{4}=0.75
\end{gathered}
$$


Normalisasi C4

$$
\begin{gathered}
R 14=\frac{3}{\max \{3 ; 4 ; 4\}}=\frac{3}{4}=0,75 \\
R 24=\frac{4}{\max \{3 ; 4 ; 4\}}=\frac{4}{4}=1 \\
R 34=\frac{4}{\max \{3 ; 4 ; 4\}}=\frac{4}{4}=1
\end{gathered}
$$

Selanjutnya hasil dari nilai rating kinerja ternormalisasi (rij) membentuk matrix ternormalisasi $(\mathrm{R})$ seperti pada persamaan di bawah ini :

$$
R=\left(\begin{array}{cccc}
0,67 & 0,8 & 1 & 0,75 \\
1 & 1 & 0,5 & 1 \\
0,5 & 0,4 & 0,75 & 1
\end{array}\right)
$$

Selanjutnya melakukan proses perangkingan seperti pada persamaan di bawah ini :

$$
\begin{array}{ll}
\mathrm{V} 1 \quad & (0,31)(0,67)+(0,23)(0,8)+(0,15)(1) \\
& +(0,31)(0,75) \\
& =0,2077+0,184+0,15+0,2325 \\
& =0,7742 \\
\mathrm{~V} 2 \quad & =(0,31)(1)+(0,23)(1)+(0,15)(0,5)+ \\
& (0,31)(1) \\
& =0,31+0,23+0,075+0,31 \\
& =0,925 \\
& =(0,31)(0,5) \quad+\quad(0,23)(0,4) \\
\mathrm{V} 3 \quad+ & (0,15)(0,75)+(0,31)(1) \\
& =0,155+0,092+0,1125+0,31 \\
& =0,6695
\end{array}
$$

\section{Rancangan Sistem Yang Diusulkan}

Dalam rancangan sistem yang diusulkan digambarkan dengan diagram UML, yaitu use case diagram, activity diagram, sequence diagram, dan class diagram.



Gambar 4.1 Use Case Diagram

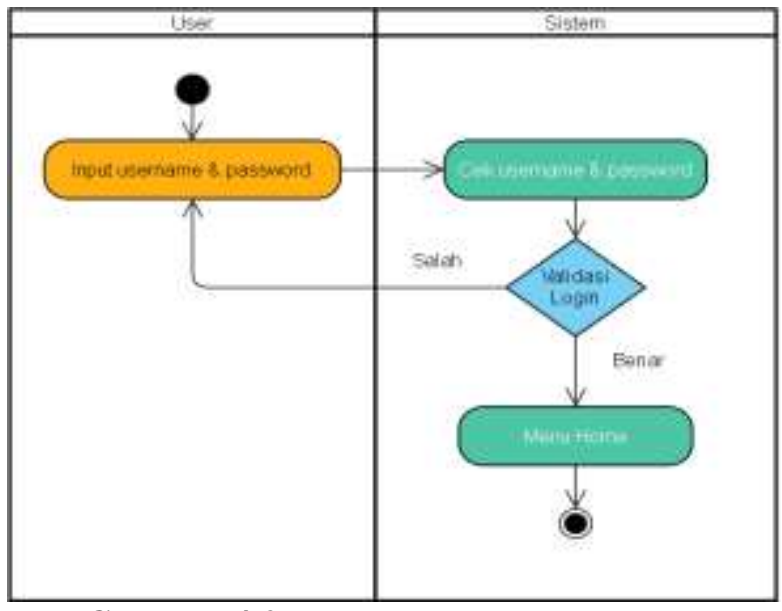

Gambar 4.2 Activity Diagram Login

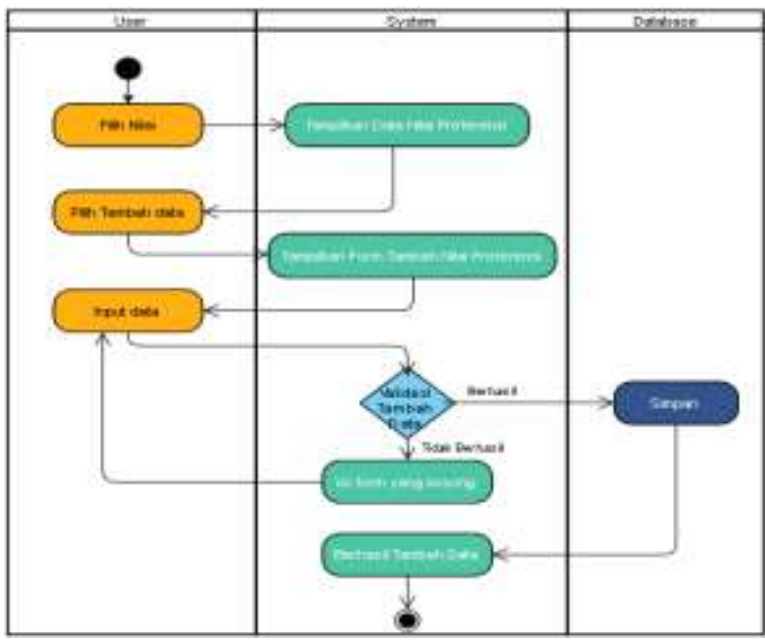

Gambar 4.3 Activity Diagram Tambah Data Nilai



Gambar 4.4 Activity Diagram Ubah Data Nilai 


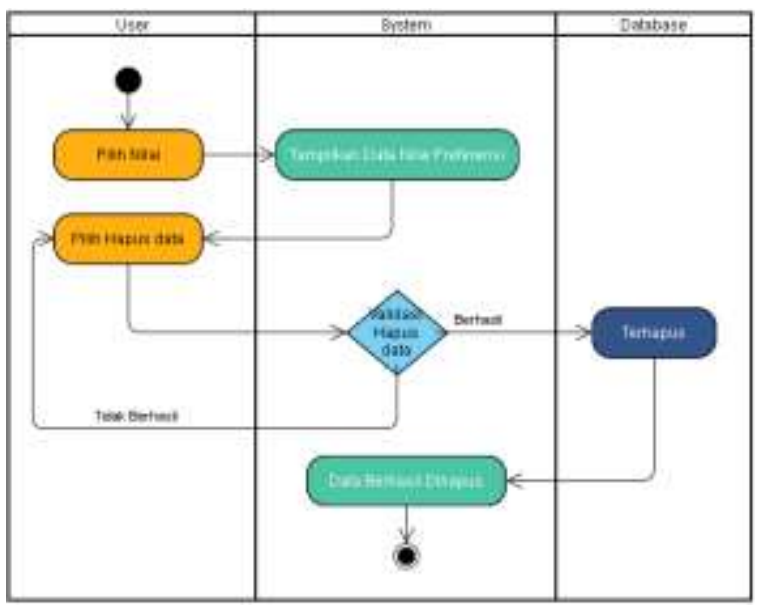

Gambar 4.5 Activity Diagram Hapus Data Nilai

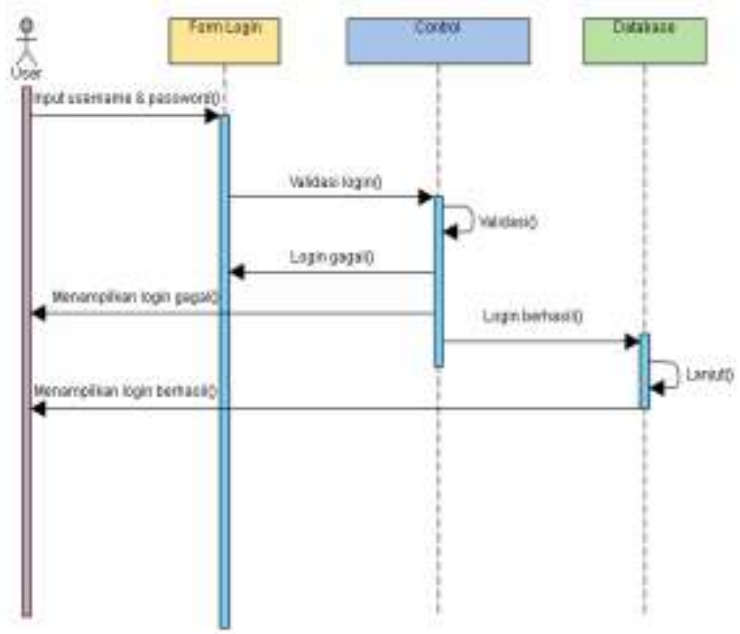

Gambar 4.6 Sequence Diagram Login

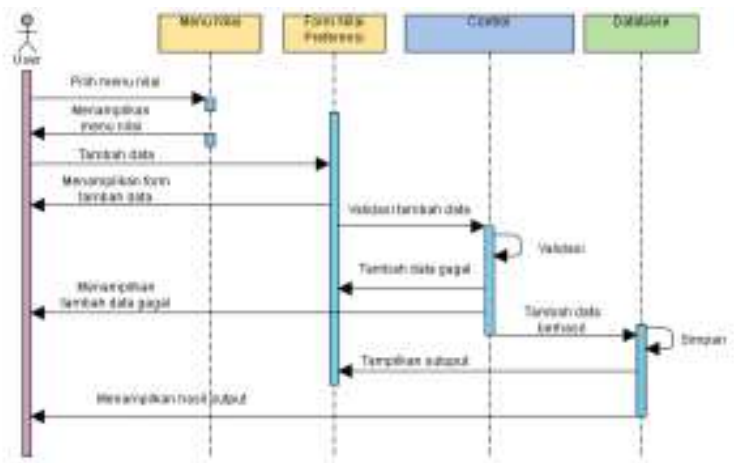

Gambar 4.7 Sequence Diagram Tambah Data Nilai

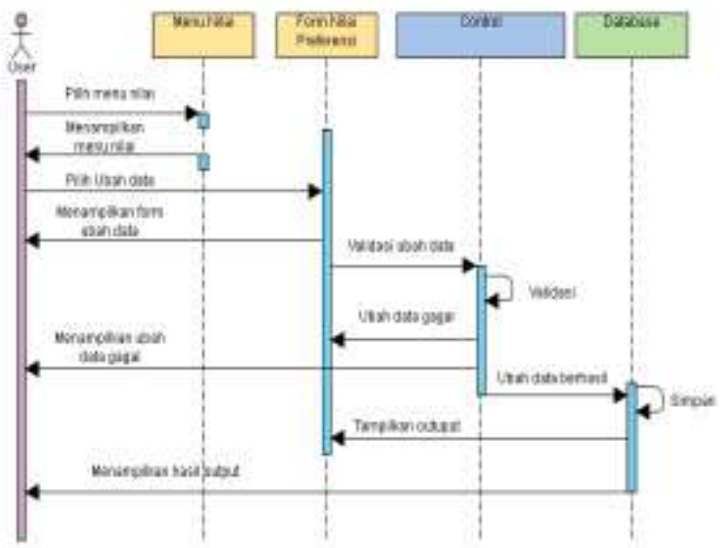

Gambar 4.8 Sequence Diagram Ubah Data Nilai

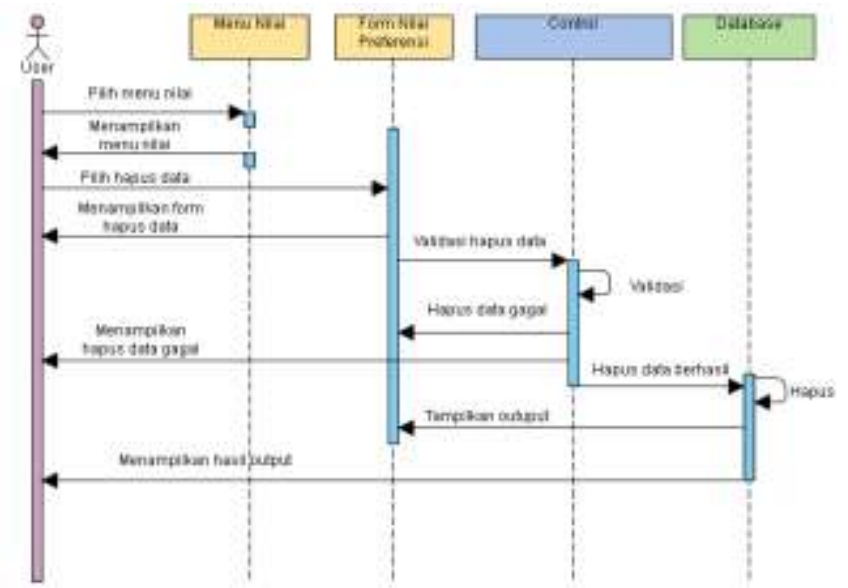

Gambar 4.9 Sequence Diagram Hapus Data Nilai
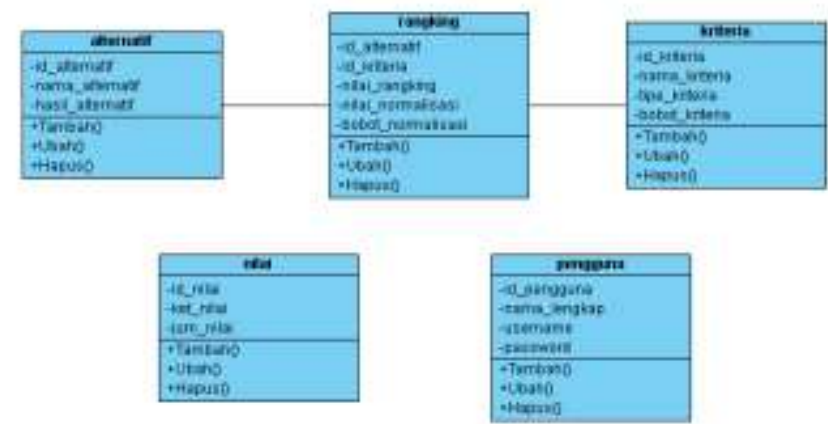

Gambar 4.10 Class Diagram 


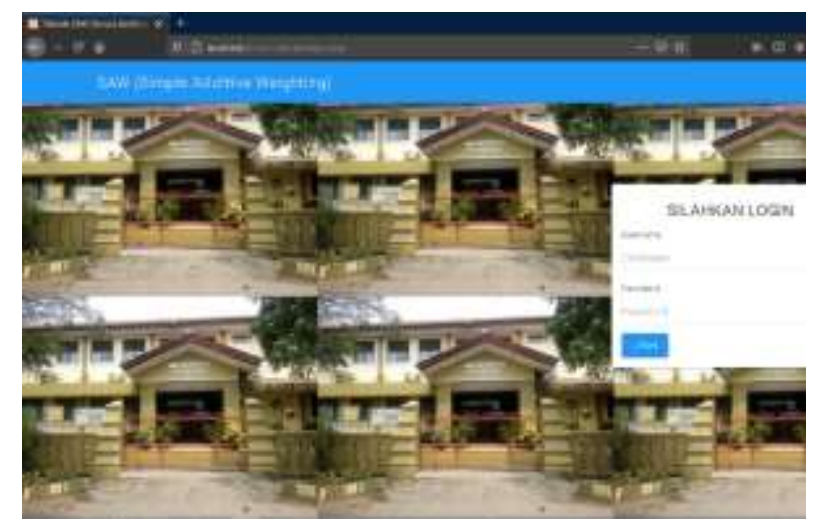

Gambar 4.11 Halaman Login



Gambar 4.12 Halaman Nilai

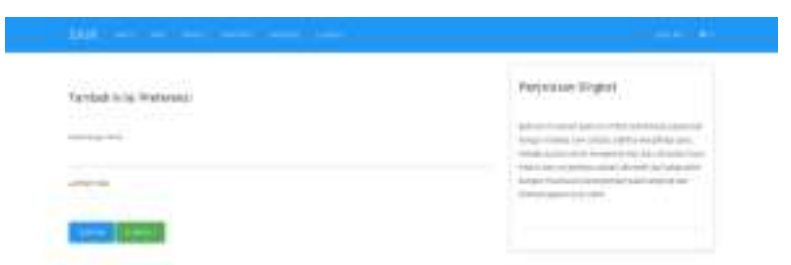

Gambar 4.13 Form Tambah Nilai Preferensi

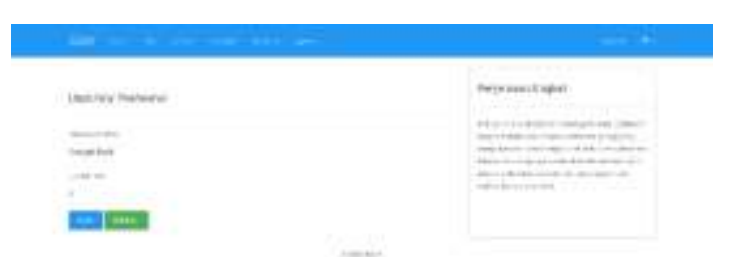

Gambar 4.14 Form Ubah Nilai Preferensi

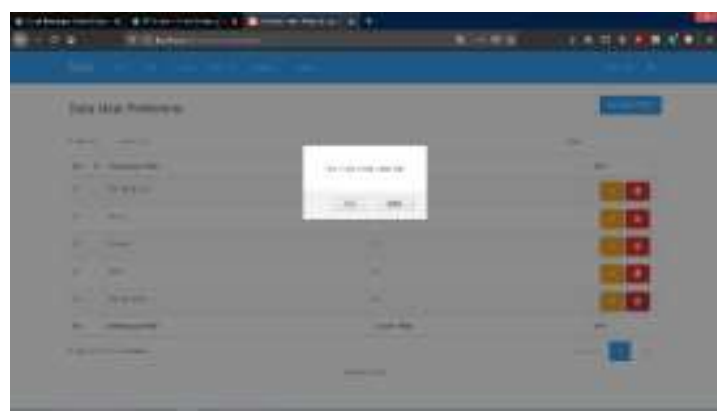

Gambar 4.15 Pop Up Hapus Nilai Preferensi

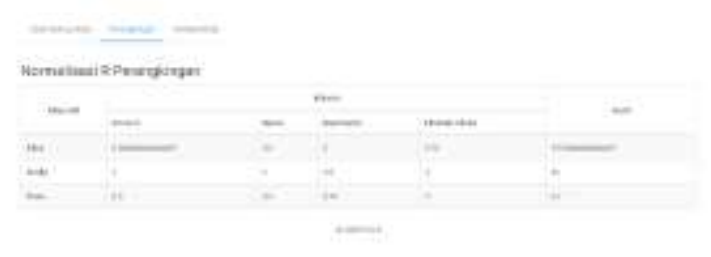

Gambar 4.16 Halaman Hasil Rangking

\section{KESIMPULAN}

Berdasarkan uraian pada bab-bab sebelumnya dan juga berdasarkan hasil pengamatan penulis selama melakukan penelitian, maka dapat diambil beberapa kesimpulan diantaranya adalah :

- Penerapan Metode SAW dalam penentuan penerima beasiswa ini dapat mempercepat proses dari sistem yang ada.

- Dengan adanya sistem yang sudah terkomputerisasi dapat mempermudah kinerja terutama guru atau admin dalam proses penentuan beasiswa.

- Pemanfaatan akan teknologi informasi yang dipadukan dengan teknologi komputer benar-benar membantu dalam menangani pengambilan keputusan. 


\section{DAFTAR PUSTAKA}

Hartono, B. (2013). Sistem Informasi Manajemen Berbasis Komputer. Jakarta Timur: Rineka Cipta.

Murniasih, E. (2010). Buku Pintar Beasiswa. Jakarta: Gagas Media.

Muslihudin, M. dan Oktafianto. (2016). Analisis dan Perancangan Sistem Informasi Menggunakan Model Terstruktur dan UML. Yogyakarta: Penerbit Andi.

Nofriansyah, D. (2014). Konsep Data Mining vs Sistem Pendukung Keputusan. Edisi I. Yogyakarta: Deepublish.

Pratama, I.P.A.E. (2014). Sistem Informasi dan Impelementasinya : Teori \& Konsep Sistem Informasi Disertai Berbagai Contoh Praktiknya Menggunakan Perangkat Lunak Open Source. Bandung: Informatika.

Sutabri, T. (2012). Konsep Sistem Informasi. Yogyakarta: Penerbit Andi.

Turban, E., Sharda, R.E, \& Delen, D. (2011). Decision Support and Business Intelligence Systems, 9th Edition. London: Pearson. 